\title{
What Factors Predict Exposure to Caste, Political and Religious Violence in India? A Cross - Sectional Survey of 1000 Indian Men
}

\author{
Alexander Broom ${ }^{1}$, David Sibbritt ${ }^{2}$, K. R. Nayar ${ }^{3}$, Pamela Nilan ${ }^{4} \&$ Emma Kirby ${ }^{1}$ \\ ${ }^{1}$ School of Social Science, The University of Queensland, Australia \\ ${ }^{2}$ Faculty of Nursing, Midwifery and Health, The University of Technology Sydney, Australia \\ ${ }^{3}$ Centre of Social Medicine and Community Health, School of Social Sciences, Jawaharlal Nehru University, New \\ Delhi, India \\ ${ }^{4}$ School of Humanities and Social Science, The University of Newcastle, Australia \\ Correspondence: Emma Kirby, School of Social Science, The University of Queensland, St Lucia QLD 4072, \\ Australia. Tel: 61-7-3346-9214. E-mail: e.kirby@uq.edu.au
}

Received: August 20, 2012 Accepted: October 4, 2012 Online Published: December 31, 2012

doi:10.5539/ass.v9n $1 \mathrm{p} 1$

URL: http://dx.doi.org/10.5539/ass.v9n1p1

The study of masculinity and violence in these two Indian states was a component of a cross-cultural project titled Masculinity and Violence in Indonesia and India. Research team: P. Nilan, A. Broom, A. Demartoto, K.R. Nayar, A. Doron, J. Germov. The 2009-2011 project was funded by an AusAID Australian Development Research Award [ADRA0800025]. The funding body had no role in, or influence over, the study design, fieldwork or analysis of the results.

\begin{abstract}
Background: Caste, political and religious violence impact considerably on the wellbeing of communities and individuals in India, where violence represents a significant problem. Given the lack of existing work on the experiences of Indian men, particularly those in Gujarat and Uttar Pradesh, this study aimed to provide baseline data on the Indian men's experiences of caste, political and religious violence in order to identify and examine the predictors of this violence.

Methods: Data were obtained from a cross-sectional survey of a sample of 1000 adult men from Uttar Pradesh and Gujarat over a two-month period in late 2009. The respondents were selected randomly from 10 cities or towns within these two provinces.

Results: The prevalence of experiences of caste violence was $90.9 \%$ ( $32.7 \%$ often and $43.8 \%$ sometimes), political violence was $94.3 \%$ ( $47.9 \%$ often $31.6 \%$ sometimes), and religious violence was $99.7 \%$ (24.3\% often and $51.8 \%$ sometimes). The results indicate that age, income, religion, education and region are important predictors of regular exposure to caste, political and religious violence.

Conclusions: The findings of this study offer timely insight into the factors which predict male exposure to caste, political and religious violence. The results of the survey have implications for policy and practice in terms of directing support towards individuals and communities at most risk of exposure to these forms of violence.
\end{abstract}

Keywords: violence, India, men, cross-sectional survey

\section{Introduction}

India has experienced significant civil unrest over much of the $20^{\text {th }}$ Century, with political, caste and religious tensions resulting in ongoing physical, mental health and social issues (Baber, 2004; Brass, 1997, 2003; Wilkinson, 2005). While levels and types of unrest and related violence have varied depending on the region examined, political, religious and caste-related tensions influence quality of life and community wellbeing in India to this day (Anand, 2005; Das, 1990; Doron, 2008; Shani, 2007). Much violence has been based on different forms of ethnic discrimination (Anthias \& Yuval-Davis, 1992), including caste and religion-driven conflict (Doron, 2010). Hindu-Muslim tensions heavily shape the Indian cultural landscape (Hansen, 1999; Hajjar, 2006) and this often results in ongoing sites of inter-ethnic and religious violence involving, at times, rape, murder, and serious physical and psychological injuries. Most research has focused on women's reports of 
exposure to violence and particularly domestic violence. Even though most political, religious and caste-related violence is either instigated by, or targets, men (Banerjee, 2005, 2006; Coleman, 2007) there has been relatively little focus on men's experiences by researchers. However, there is considerable work that illustrates the interplay between masculinity and violence in India (Mehta, 2000; see also Broom et al., 2012). An objective of this study was to examine men's self-reported levels of exposure to various forms of violence in Gujarat and Uttar Pradesh, two key Indian states with varying political, caste and religious tensions (Doron, 2008; Varadarajan, 2002). Moreover, the study aimed to document the main predictors of self-reported exposure to violence in order to inform the targeting of policy and support programs toward those groups most at risk. Here, we build upon our previous findings on men's experiences family, domestic and honour-related violence in these two geographic areas (Broom et al., 2012), by turning our focus towards more collective forms of violence.

\subsection{Violence: Caste, Religion and Politics}

India has significant and ongoing religious, political and caste-related tensions. Communal tensions and violence tend to be orientated around dynamics between the Hindu majority and large (but minority) Muslim Indians (Anand, 2007). The tensions between Pakistan and India are often given centre stage internationally, but it is perhaps the internal dynamics, tensions and sites of everyday conflict between Muslims and Hindus that define the Indian cultural underpinnings of violence (Baber, 2004; Das, 1990; Brass, 2004). Hindu-Muslim relations, as manifested in the temple/mosque violence in Ayodhya and the more recent Gujarat riots of 2002, continue to generate heated debate and political tensions, and unsettle everyday life in India (Varadarajan, 2002; Baxi, 2002; Mehta \& Mehta, 2010).

Furthermore, violence and physical aggression are key elements of inter-caste relations (Krishnan, 2005), the expression of Indian masculinities (Banerjee, 2005, 2006), and resistance to caste-based subordination (Shani, 2007). While the dalit reassertion movement has changed the landscape of caste dynamics in many areas of India, there remain caste-related tensions/violence within the Indian cultural landscape which feed into sites of violence in specific communities (Jafferlot, 2003). Particularly in areas where there exist significant economic deprivation (UP and Bihar are prime examples), caste tensions still dominate social dynamics, often erupting into explicit and even deadly forms of street violence (Chowdhry, 1997; Narayan, 2006). Communities are often divided or segregated geographically along class, caste and or religious lines, with cross-sector interactions creating potential reconciliation but also violent encounters. While the extreme forms of marginalisation emerging from 'untouchability' are now couched as 'identity politics', caste-based tensions and violence still remain very much a part of many Indian's everyday lives (Doron, 2008, 2010; Shani, 2007; Krishnan, 2005).

\subsection{Political Tensions and Sites of Violence}

The prominence of the Bharatiya Janata Party in Indian politics in the early $21^{\text {st }}$ Century reflects a wider movement in India toward a more right-wing Hindu politic in certain geo-political areas. Such political and ideological shifts have highlighted and enhanced wider political divides in the Indian cultural landscape. Such dynamics have historical resonances, some of which are anchored in pre-modern and colonial practices and policies of ethnic/caste/religious 'delineation'. The emergence of, and surge in support for, the Hindu right-wing in Indian political life and governance in the new millennium has enhanced political divides along religious lines, resulting in ongoing violence and civil unrest. The mobilisation of men by political parties is a common practice and can result in public unrest and violent confrontations between competing parties.

\section{Methods}

\subsection{Settings}

This study was conducted in Uttar Pradesh (UP) and Gujarat. A detailed outline of these settings may be found in our previously published article in this journal (Broom et al., 2012) which focused on exposure to family, domestic and honour-related violence, and is drawn from the same survey data. Briefly here, we reiterate the areas of UP and Gujarat provide many potentially important contrasts in terms of the interplay between violence and economic and social developments, grounded within contexts of ongoing political tensions.

\subsection{Definitions of Violence}

A standard definition of violence is hard to arrive at and is likely to be contested (Jackman, 2002). We wanted to encourage a wide range of perspectives and experiences so the following broad definition of violence was provided to the participants: any act - physical, verbal or emotional - that is intended to, or results in, harm to another person or group. Specific survey questions asked about different kinds of violence. Here we focus on violence that was perceived to be on a basis of caste, politics or religion, rather than, say, domestic violence, family violence or other forms of interpersonal violence (see Broom et al., 2012). In recording the men's 
perceptions we recognise it is possible others involved in these sites and enactments of violence might not have considered them based on the same factors as the participants. Nevertheless, we view their accounts as an important contribution to broadening our understanding of violence in India. To enhance consistency, the men surveyed had each form of violence explained to them by the researcher. The men were asked to respond in relation to their personal experiences of and exposure to violence.

\subsection{Study Sample}

The sample of 1000 men was obtained from Uttar Pradesh and Gujarat. This non-probability purposive approach included smaller representative samples from 5 cities/towns in UP and Gujarat. A minimum of 30 participants was selected at random from each city/town. Men were approached by a researcher in public spaces (rather than within their homes) in 191 locations within the two sets of 5 cities/towns, so as to ensure a spread of representation. Three men in Gujarat refused to participate, as did seven men in UP, within an overall response rate of over $99 \%$. The final sample was analysed in terms of demographic characteristics, and was found to be closely in alignment with those of the general populations of males in the two States. As outlined previously (Broom et al., 2012), participation in the survey lasted for around 20 minutes, and the survey was piloted with 30 participants prior to commencement. The survey was conducted according to the language of the participant (in Gujarati or Hindi), and all translations to English were confirmed by an independent specialist.

\subsection{Outcome Measures}

Each participant was asked how if they had experienced various forms of violence 'never', 'rarely', 'sometimes' or 'often'. Participants were not questioned about being the perpetrators or victims of violence in line with evidence that such lines of questioning may limit the honest reporting of exposure to violence (Jejeebhoy, 1998). The findings we discuss below, therefore, will be augmented by future research which focuses on the contexts of experience of forms of violence, based on the predictors of extent of exposure we provide here. Participants were deemed to have experienced caste, political or religious-related violence if they indicated experience in this form of violence either 'sometimes' or 'often'.

\subsection{Statistical Analyses}

Simple and multiple logistic regression models were used to analyse associations with independent variables for each category of violence. A backwards stepwise elimination procedure was employed to determine the models of multiple logistic regression. Hosmer-Lemeshow goodness of fit tests were used to check the fit of the final multiple logistic regression models.

\section{Results}

\subsection{Lifetime Prevalence in Exposure to Caste, Political and Religious Violence}

The lifetime prevalence of experiencing caste-related violence for the men in this sample was $90.9 \%$. This included $32.7 \%$ having experienced caste-related violence often and $43.8 \%$ having experienced caste-related violence sometimes. The lifetime prevalence of experiencing political violence for the men in this sample was $94.3 \%$. This included $47.9 \%$ having experienced political violence often and $31.6 \%$ having experienced political violence sometimes. The lifetime prevalence of experiencing religious violence for the men in this sample was $99.7 \%$. This included $24.3 \%$ having experienced religious violence often and $51.8 \%$ having experienced religion-related violence sometimes. 


\subsection{Predictors of Exposure to Caste-Related Violence}

Table 1. Distribution of study sample by their characteristics and univariate logistic regression analysis for the association between these characteristics and the different forms of violence $(\mathrm{n}=1,000)$

\begin{tabular}{|c|c|c|c|c|}
\hline Dependent Variable & $\begin{array}{l}\text { Distribution of } \\
\text { participants n (\%) }\end{array}$ & $\begin{array}{l}\text { Caste-Related } \\
\text { Violence }\end{array}$ & $\begin{array}{l}\text { Political } \\
\text { Violence }\end{array}$ & $\begin{array}{l}\text { Religion-Related } \\
\text { Violence }\end{array}$ \\
\hline \multicolumn{5}{|l|}{ Individual level } \\
\hline \multicolumn{5}{|l|}{ Age group (years) } \\
\hline$<30$ & $311(31.1)$ & 0.285 & $<0.01$ & $<0.01$ \\
\hline $30-39$ & $362(36.2)$ & & & \\
\hline$\geq 40$ & $327(32.7)$ & & & \\
\hline \multicolumn{5}{|l|}{ Education } \\
\hline primary school $^{*}$ & $93(9.3)$ & $<0.01$ & 0.477 & $<0.01$ \\
\hline secondary school & $481(48.1)$ & & & \\
\hline tertiary & $426(42.6)$ & & & \\
\hline \multicolumn{5}{|l|}{$\begin{array}{l}\text { Income (INR per } \\
\text { month) }\end{array}$} \\
\hline$<5000$ & $425(42.5)$ & $<0.01$ & $<0.01$ & 0.052 \\
\hline $5000-9999$ & $426(42.6)$ & & & \\
\hline$\geq 10000$ & $149(14.9)$ & & & \\
\hline \multicolumn{5}{|l|}{ Religion } \\
\hline Muslim & $257(25.7)$ & $<0.01$ & $<0.01$ & 0.030 \\
\hline Hindu & $706(70.6)$ & & & \\
\hline other & $37(3.7)$ & & & \\
\hline \multicolumn{5}{|l|}{ Marital status } \\
\hline never married & $95(9.5)$ & 0.253 & 0.435 & 0.179 \\
\hline married & $859(85.9)$ & & & \\
\hline sep/div/wid & $46(4.6)$ & & & \\
\hline \multicolumn{5}{|l|}{ Number of children } \\
\hline 0 & $124(12.4)$ & $<0.01$ & $<0.01$ & 0.049 \\
\hline $1-2$ & $436(43.6)$ & & & \\
\hline$\geq 3$ & $440(44.0)$ & & & \\
\hline \multicolumn{5}{|l|}{ State } \\
\hline Gujarat & $500(50 \%)$ & $<0.01$ & $<0.01$ & $<0.01$ \\
\hline Uttar Pradesh & $500(50 \%)$ & & & \\
\hline \multicolumn{5}{|l|}{$\begin{array}{l}\text { Religious } \\
\text { organisation }\end{array}$} \\
\hline yes (a member) & $153(15.3)$ & 0.305 & 0.024 & 0.078 \\
\hline no (not a member) & $847(84.7)$ & & & \\
\hline \multicolumn{5}{|l|}{ Political party } \\
\hline yes (a member) & $168(16.8)$ & 0.091 & 0.017 & 0.866 \\
\hline no (not a member) & $832(83.2)$ & & & \\
\hline
\end{tabular}

Table 1 presents the distribution of participants by various characteristics (independent variables), and the levels of significance ( $p$-values) of simple logistic regression models to examine the association between these independent variables and the three forms of violence. Of the 9 independent variables, 5 were significantly associated with caste-related violence. 
Table 2. Significant predictors of the different forms of violence experienced assessed through multiple logistic regression $(\mathrm{n}=1,000)$

\begin{tabular}{|c|c|c|c|}
\hline Dependent Variable & $\begin{array}{l}\text { Caste-Related Violence } \\
\text { AOR }(95 \% \mathrm{CI})\end{array}$ & $\begin{array}{l}\text { Political Violence AOR } \\
(95 \% \text { CI })\end{array}$ & $\begin{array}{l}\text { Religion-Related } \\
\text { Violence AOR }(95 \% \text { CI })\end{array}$ \\
\hline \multicolumn{4}{|l|}{ Individual level } \\
\hline \multicolumn{4}{|l|}{ Age group (years) } \\
\hline$<30$ & & reference & reference \\
\hline $30-39$ & & $1.47(0.99-2.19)$ & $1.55(1.03-2.35)$ \\
\hline$\geq 40$ & & $2.80(1.80-4.36)$ & $3.51(2.11-5.83)$ \\
\hline \multicolumn{4}{|l|}{ Education } \\
\hline primary school* & reference & & reference \\
\hline secondary school & $0.96(0.52-1.75)$ & & $0.54(0.28-1.04)$ \\
\hline tertiary & $0.49(0.26-0.90)$ & & $0.38(0.19-0.75)$ \\
\hline \multicolumn{4}{|c|}{ Income (INR per month) } \\
\hline$<5000$ & reference & reference & \\
\hline $5000-9999$ & $0.59(0.40-0.87)$ & $0.96(0.65-1.40)$ & \\
\hline$\geq 10000$ & $0.49(0.30-0.81)$ & $0.48(0.29-0.79)$ & \\
\hline \multicolumn{4}{|l|}{ Religion } \\
\hline Muslim & reference & reference & reference \\
\hline Hindu & $0.38(0.17-0.84)$ & $0.02(0.002-0.17)$ & $0.73(0.29-1.84)$ \\
\hline other & $0.27(0.17-0.42)$ & $0.01(0.001-0.06)$ & $0.56(0.39-0.82)$ \\
\hline \multicolumn{4}{|l|}{ Marital status } \\
\hline \multicolumn{4}{|l|}{ never married } \\
\hline \multicolumn{4}{|l|}{ married } \\
\hline \multicolumn{4}{|l|}{ sep/div/wid } \\
\hline \multicolumn{4}{|l|}{ Number of children } \\
\hline 0 & & & reference \\
\hline $1-2$ & & & $0.41(0.24-0.70)$ \\
\hline$\geq 3$ & & & $0.31(0.16-0.58)$ \\
\hline \multicolumn{4}{|l|}{ State } \\
\hline Gujarat & reference & reference & reference \\
\hline Uttar Pradesh & $0.25(0.18-0.36)$ & $0.35(0.25-0.51)$ & $1.47(1.07-2.00)$ \\
\hline \multicolumn{4}{|l|}{ Religious organisation } \\
\hline \multicolumn{4}{|l|}{ yes (a member) } \\
\hline \multicolumn{4}{|l|}{ no (not a member) } \\
\hline \multicolumn{4}{|l|}{ Political party } \\
\hline \multicolumn{4}{|l|}{ yes (a member) } \\
\hline no (not a member) & & & \\
\hline
\end{tabular}

However, after controlling for other factors within the multiple logistic regression model, only 4 variables remained statistically significant predictors of caste-related violence (Table 2). Specifically, the odds of a male with a tertiary education experiencing caste-related violence is 0.49 (95\% CI: $0.26-0.90)$ times less than a male with only a primary school education. Males with a monthly income of 5000-9999 INR are 0.59 (95\% CI: $0.40-0.87$ ) times less likely to experience caste-related violence compared to males with less than 5000 INR per month. Males with a monthly income of 10000 INR or more are 0.49 (95\% CI: $0.30-0.81$ ) times less likely to experience caste-related violence compared to males with less than 5000 INR per month. Compared to Muslim males, Hindu males are 0.38 (95\% CI: 0.17-0.84) times less likely to experience caste-related violence, while males of an 'other' religion are 0.27 (95\% CI: 0.17-0.42) times less likely to experience caste-related violence. 
The odds of males from the State of Uttar Pradesh experiencing caste-related violence is 0.25 (95\% CI: $0.18-0.36)$ times that of males from the State of Gujarat. The Hosmer-Lemeshow test $(p=0.26)$ indicated that the multiple logistic regression model for caste-related violence was a good fit.

\subsection{Predictors of Exposure to Political Violence}

The simple logistic regressions used to examine the association between the various characteristics and political violence shown in Table 1 revealed that, of the 9 independent variables, 5 were significantly associated with political violence. After controlling for other factors within the multiple logistic regression model, only 4 of these variables remained statistically significant predictors of political violence (Table 2). Specifically, males aged 40 years or more are 2.80 (95\% CI: 1.80-4.36) times more likely to experience political violence than males aged 30 years or less. Males with a monthly income of 10000 INR or more are 0.48 (95\% CI: 0.29-0.79) times less likely to experience political violence compared to males with less than 5000 INR per month. Compared to Muslim males, Hindu males are 0.02 (95\% CI: 0.002-0.17) times less likely to experience political violence, while males of an 'other' religion are 0.01 (95\% CI: 0.001-0.06) times less likely to experience political violence The odds of males from the State of Uttar Pradesh experiencing political violence is 0.35 (95\% CI: $0.25-0.51$ ) times that of males from the State of Gujarat. The Hosmer-Lemeshow test $(\mathrm{p}=0.21)$ indicated that the multiple logistic regression model for political violence was also a good fit.

\subsection{Predictors of Exposure to Religious Violence}

The simple logistic regressions used to examine the association between the various characteristics and religion-related violence shown in Table 1 revealed that, of the 9 independent variables, 5 were significantly associated with religion-related violence. After controlling for other factors within the multiple logistic regression model, the same 5 variables remained statistically significant predictors of religion-related violence (Table 2). Specifically, the odds of a male aged 30-39 years or a male aged 40 years or more experiencing religion-related violence is 1.55 (95\% CI: 1.03-2.35) and 3.51 (95\% CI: 2.11-5.83) times more than a male aged 30 years or less, respectively. The odds of males with a tertiary education experiencing religion-related violence are 0.38 (95\% CI: $0.19-0.75)$ times less than males with a primary school education. Compared to Muslim males, males of an 'other' religion are 0.56 (95\% CI: 0.39-0.82) times less likely to experience religion-related violence. In comparison to males with no children, males with one or two children and males with 3 or more children are 0.41 (95\% CI: 0.24-0.70) and 0.31 (95\% CI: 02.16-0.58) times less likely to experience religion-related violence, respectively. The odds of males from the State of Uttar Pradesh experiencing religion-related violence is 1.47 (95\% CI: 1.07-2.00) times that of males from the State of Gujarat. The Hosmer-Lemeshow test $(\mathrm{p}=0.58)$ indicated that the multiple logistic regression model for religion-related violence was once again a good fit.

\section{Discussion}

This paper presents findings of the first cross-sectional survey of Indian men's exposure to religious, political and caste-related violence. Building on our previous findings from this participant cohort on men's experiences of family, domestic and honour-related violence (see Broom et al., 2012), we have sought in this paper to focus on the provision of baseline data and predictors of self-reported exposure to religious, political and caste-related violence. We acknowledge that the results are self-reported, so there is potential for recall bias. Furthermore, we deliberately did not ask men about their role in the violence as explained above. We also acknowledge that religious, political and caste dynamics are complex and subjective concepts and that these forms of violence often interplay in everyday life. However, the data illustrate meaningful and statistically significant differences in these men's direct experiences of religious, political and caste-related violence. At a basic level, the data illustrates and bears out Tilly's (2003) argument regarding the widespread exposure to violence amongst any male population. Furthermore, that exposure to various kinds of violence is not evenly distributed in the male population (see also Broom et al., 2012).

In these two Indian states certain socio-demographic factors are identified as strong predictors of exposure. That is, there exist clear differences in relation to the types of men who experience, and are exposed to, particular forms of violence. The four independent variables of age, income, education and religion were sustained as factors that predict, to a large extent, caste, religious and political violence in India. Location was also important, with higher levels of exposure to violence indicated in Uttar Pradesh where levels of poverty are high.

Neither age, education, religion, nor income were predictors of all three forms of violence. Rather, being older, non-Muslim and low-educated predicted exposure to religious violence, while being Hindu, having a low income and low education predicted exposure to caste-related violence. Older age and low income were predictors of exposure to political violence. It seems likely that these results reflect the fact that as Indian men get older, they are more likely to have involvement with political or religious activities. This suggests that men will be at greater 
risk from exposure to violence as they get older, reversing the common assumption that younger men are most 'at risk' of violence (either as victims or perpetrators). Caste-related violence, however, showed no differences between age-groups, illustrating a perhaps expected pattern that caste-related dynamics and subsequent exposure to violence persists over the life course. This reinforces previous work in India indicating the persistence of health inequalities related to caste/class over the life course (Subramanian et al., 2006). That is, it is still extremely difficult to surpass caste and class structures in these two states, particularly in Uttar Pradesh.

This study shows that lower income levels greatly increase the likelihood of exposure to caste and political violence, indicating that income acts as an insulator from various forms of social inequality and forms of aggression and/or violence (Subramanian et al., 2006). While this is perhaps not surprising, it remains an important fact that poorer men are more likely to experience, be involved in, and be the victims of violence. This kind of structural inequality as a predictor has often been emphasised in studies of violence against women of lower socio-economic status but the same point has not so often been made regarding men. It is interesting to note, however, that the income gap for religious violence was not significant. It would seem that male religious violence cuts across socio-economic strata to the extent this is represented by income.

Perhaps reflective of the vastly lower socioeconomic status compared to Gujarat, men in Uttar Pradesh reported much higher levels of exposure to all three forms of violence. This is despite considerable, well-publicised political, religious and caste-related tensions in Gujarat (Varadarajan, 2002; Krishnan, 2005). Our findings indicate that regardless of specific/intense sites of conflict and violence, the socio-economic challenges facing Uttar Pradesh promote broader and persistent exposure to violence. It seems that while ethnic, caste, political and religious tensions simmer in Gujarat, socio-economic development may have significantly reduced the prevalence and impact of violence on individuals and communities.

\section{Conclusion}

Violence has a major impact on individual lives, community wellbeing and the effectiveness of development programs including health service delivery. Much violence is driven by political, religious and caste-related tensions and men are central to such acts. The levels of exposure, as illustrated in this study, present a major burden on the already strained development and health services in Gujarat and Uttar Pradesh. The results presented here indicate the degree of exposure to these forms of violence amongst Indian men as well as the social patterning of these experiences. While research with women has illustrated the ways in which their exposure to violence is mediated by socio-demographics, no such research has been done with Indian men. These results suggest that age, income, religion, education and geographical location are all key predictors of exposure to violence in India. Specifically, that people from the lower socio-economic echelons are more exposed to violence which in turn could explain regional differences in experiences of violence.

\section{References}

Anand, A. (2007). Anxious sexualities: Masculinity, nationalism \& violence. The British Journal of Politics and International Relations, 9, 257-269. http://dx.doi.org/10.1111/j.1467-856X.2007.00282.x

Anand, D. (2005). Violence of security: Hindutva in India. The Commonwealth Journal of International Affairs, 94(379), 201-213.

Anthias, F., \& Yuval-Davis, N. (1992). Racial boundary: Race, nation, gender, colour and class and the anti-racist struggle. New York, NY: Routledge.

Baber, Z. (2004). Race, religion and riots: The "racialization" of communal identity and conflict in India. Sociology, 38(4), 701-718. http://dx.doi.org/10.1177/0038038504045860

Banerjee, S. (2005). Make me a man! Masculinity, Hinduism \& nationalism in India. New York, NY: State University of New York Press.

Banerjee, S. (2006). Armed masculinity, Hindu nationalism and female political participation in India. International Feminist Journal of Politics, 8(1), 62-83. http://dx.doi.org/10.1080/14616740500415482

Baxi, U. (2002). The second Gujarat catastrophe. Economic and Political Weekly, 37(34), 3519-3531.

Brass, P. (1997). Theft of an idol: Text and context in the representation of collective violence. Princeton, NJ: Princeton University Press.

Brass, P. (2003). The production of Hindu-Muslim violence in contemporary India. Seattle, WA: University of Washington Press.

Brass, P. (2004). The body as symbol: History, memory and communal violence. Manushi, 141, 22-31. 
Broom, A., Sibbritt, D., Nayar, K.R., Doron, A., \& Nilan, P. (2012). Men’s Experiences of Family, Domestic and Honour-Related Violence in Gujarat and Uttar Pradesh, India. Asian Social Science, 8(6), 3-10. http://dx.doi.org/10.5539/ass.v8n6p3

Chowdhry, P. (1997). Enforcing cultural codes: Gender and violence in Northern India. Economic and Political Weekly, 32(19), 1019-1028.

Coleman, L. (2007). The gendered violence of development. The British Journal of Politics \& International Relations, 9(2), 204-219. http://dx.doi.org/10.1111/j.1467-856X.2007.00288.x

Das, V. (1990). Communities, riots, survivors - the South Asian experience. In V. Das (Ed.), Mirrors of Violence: Communities, riots and survivors in South Asia (pp. 1-36). New Delhi: Oxford University Press.

Doron, A. (2008). Caste, occupation \& politics on the Ganges. Aldershot: Ashgate.

Doron, A. (2010). Caste away? Subaltern engagement with the modern Indian State. Modern Asian Studies, 44(4), 753-783. http://dx.doi.org/10.1017/S0026749X0900393X

Hajjar, L. (2006). Religion, state power, and domestic violence in Muslim societies: A framework for $\begin{array}{llllll}\text { comparative } \quad \text { analysis. } & \text { Law } & \text { Social } & \text { Inquiry, } & \text { 29, } & \text { 1-38. }\end{array}$ http://dx.doi.org/10.1111/j.1747-4469.2004.tb00329.x

Hansen, T. (1999). The Saffron wave: Democracy and Hindu nationalism in modern India. Princeton, NJ: Princeton University Press.

Jackman, M. (2002). Violence in social life. Annual Review of Sociology, 28(1), $387-414$. http://dx.doi.org/10.1146/annurev.soc.28.110601.140936

Jafferlot, C. (2003). India's silent revolution: The rise of lower castes in North India. London: C. Hurst \& Co.

Jejeebhoy, S. (1998). Wife-beating in rural India. Economic and Political Weekly, 33, 855-862.

Krishnan, S. (2005). Gender, caste, and economic inequalities and marital violence in rural South India. Health Care for Women International, 26, 87-99. http://dx.doi.org/10.1080/07399330490493368

Mehta, D. (2000). Circumcision, body, masculinity: The ritual wound and collective violence. In V. Das, A. Kleinman, M. Ramphele, \& P. Reynolds (Eds.), Violence and subjectivity (pp. 79-101). Berkeley, CA: University of California Press.

Mehta, N., \& Mehta, M. (2010). Gujarat beyond Gandhi: notes on identity, culture and society. South Asian History and Culture, 1(4), 467-479. http://dx.doi.org/10.1080/19472498.2010.507019

Narayan, B. (2006). Women heroes and Dalit assertion in North India. New Delhi: Sage.

Shani, O. (2007). Communalism, caste and Hindu nationalism. Cambridge: Cambridge University Press. http://dx.doi.org/10.1017/CBO9780511607936

Subramanian, S., Nandy, S., Irving, M., Gordon, D., Lambert, H., \& Davey Smith, G. (2006). The mortality divide in India: the differential contributions of gender, caste, and standard of living across the life course. American Journal of Public Health, 96(5), 818-825. http://dx.doi.org/10.2105/AJPH.2004.060103

Tilly, C. (2003). The politics of collective violence. New York: Cambridge University Press.

Varadarajan, S. (2002). Gujarat: The making of a tragedy. New Delhi: Penguin.

Wilkinson, S. (Ed.). (2005). Religious politics and communal violence. New Delhi: Oxford University Press. 